\title{
Sistem Informasi Pengumuman Program Studi Di Perguruan Tinggi $X$
}

\author{
Angga Setiyadi ${ }^{1}$, Eko Budi Setiawan² \\ Universitas Komputer Indonesia, Jl. Dipatiukur, Jawa Barat, Indonesia \\ 1anggasetiyadi@gmail.com \\ ²ekobudisetiawan@ymail.com
}

\begin{abstract}
Abstrak
Teknologi informasi merupakan hasil olah pikir manusia untuk mengembangkan tata cara atau sistem tertentu dan menggunakannya untuk menyelesaikan persoalan dalam hidupnya. Penyampaian informasi saat ini tidak lagi melalui media cetak, namun berangsur akan bergeser pada penggunaan media digital elektronik. Pengumuman dapat diartikan sebagai pesan yang disampaikan kepada setiap orang yang menjadi tujuan atau sasaran informasi yang dituju. Penelitian ini membahas mengenai sistem informasi pengumuman yang dapat menggantikan media pengumuman yang masih konvensional. Dengan adanya sistem informasi pengumuman ini menjadikan setiap dosen dan sekretariat di salah satu program studi pada Perguruan Tinggi $X$ tidak perlu lagi untuk mencetak dan menempelkan pengumuman di papan informasi yang tersedia, namun dapat secara digital dengan memasukan pengumuman kedalam sistem untuk kemudian pengumuman tersebut akan ditampilkan di setiap layar televisi atau monitor yang tersebar dan tersedia di setiap area kampus. Hal tersebut dapat menjadikan proses penyampaian informasi menjadi lebih efektif dan efisien apabila dibandingkan dengan media cetak.
\end{abstract}

Kata kunci: Sistem Informasi, Pengumuman, Media Informasi, Akademik, Perguruan Tinggi

\begin{abstract}
Information technology is the result of a human mind to develop ordinances or specific systems and use them to solve problems in life. Submission of information today is no longer through the print media, but will gradually shift to the use of digital electronic media. The announcement can be interpreted as a message delivered to every person who is the target destination or destination information. This study discusses the announcement of information systems that can replace conventional media announcements still. With this information system of this announcement makes any lecturer and secretariat in one program studi in College $X$ no longer need to print and posting notices on board the information available, but may be digital by entering the announcement into the system to afterwards the announcement will be displayed on each screen television or monitor the spread and available in every area of the campus. This can make the process of delivering information to become more effective and efisien if compared to the print media.
\end{abstract}

Keywords: System Information, Announcement, Media Information, Academic, College

\section{Pendahuluan}

Teknologi informasi merupakan hasil olah pikir manusia untuk mengembangkan tata cara atau sistem tertentu dan menggunakannya untuk menyelesaikan persoalan dalam hidupnya. Penyampaian informasi saat ini tidak lagi melalui media cetak, namun akan berubah pada penggunaan media elektronik. Pengumuman dapat diartikan sebagai pesan yang disampaikan kepada setiap orang yang menjadi setiap orang yang menjadi tujuan atau menjadi sasaran informasi yang dituju. Salah satu contoh penggunaan media elektronik adalah penyampaian informasi serta sebagai media promosi. Media elektronik tersebut dapat kita lihat disetiap lokasi, 
mulai dari pusat perbelanjaan, instansi pemerintah, instansi pendidikan ataupun instansi tempat pelayanan masyarakat.

Perguruan Tinggi $X$ yang menjadi tempat penelitian ini dilakukan merupakan sebuah perguruan tinggi swasta yang ada di Kota Bandung, Jawa Barat. Sebelum adanya sistem informasi pengumuman ini dibangun, Program Studi di Perguruan Tinggi $X$ masih menggunakan cara yang manual dalam penyampaian informasi kepada setiap mahasiswa di lingkungan program studi. Salah satu contoh penyampaian informasi kepada mahasiswa yaitu dengan menempelkan lembar pengumuman di papan informasi yang tersedia di area kampus. Apabila ada informasi baru yang akan di umumkan kepada mahasiswa, maka dosen atau pihak sekretariat akan mencetak dan memperbanyak pengumuman tersebut terlebih dahulu, untuk kemudian pengumuman tersebut ditempelkan di papan informasi program studi.

Hal inilah yang membuat peneliti tertarik untuk melakukan penelitian mengenai pembangunan sistem informasi pengumuman Program Studi di Perguruan Tinggi $X$. Dengan sistem informasi pengumuman ini, setiap dosen dan sekretariat program studi diharapkan tidak perlu lagi untuk mencetak dan menempelkannya di papan informasi program studi karena data pengumuman akan tersimpan di dalam database sistem dan akan menampilkannya di layar monitor ataupun televisi yang tersedia di beberapa area program studi.

\section{Metodologi Penelitian}

Metodologi penelitian pada pembangunan sistem informasi pengumuman program studi di Perguruan Tinggi $X$ yang digunakan adalah metodologi analisis deskriptif. Metodologi analisis deskriptif merupakan metode yang menggambarkan setiap fakta dan informasi dalam situasi dan kondisi atau peristiwa secara sistematis, faktual dan akurat. Metodologi penelitian ini memiliki dua tahapan, yaitu tahap pengumpulan data dan tahap pengembangan perangkat lunak.

\subsection{Metode Pengumpulan Data}

Teknik yang digunakan dalam pengumpulan data yakni penelitian secara deskriptif, yaitu suatu metode penelitian yang memberikan gambaran secara obyektif tentang suatu permasalahan yang ada. Metode pengumpulan data yang dilakukan dalam penelitian ini adalah sebagai berikut:

a. Interview

Metode ini dilakukan dengan cara mengumpulkan data dalam bentuk personal yang dilaksanakan oleh interviewer yang dalam hal ini adalah peneliti kepada para stackholder yang berkaitan dengan proses publikasi atau penyampaian informasi pengumuman di salah satu Program Studi pada Perguruan Tinggi X.

b. Studi Literatur

Cara yang dilakukan untuk mengumpulkan data pada penelitian ini yakni dengan cara menghimpun data-data atau sumber-sumber yang berhubungan dengan topik yang diteliti. Studi literatur dalam penelitian ini didapat dari berbagai sumber, jurnal, buku dokumentasi, internet dan bahan pustaka lainnya. Proses ini dilakukan untuk mencari dan mengumpulkan segala informasi yang diperlukan untuk pembangunan sistem informasi pengumuman Program Studi di Perguruan Tinggi $X$.

c. Observasi

Observasi adalah seluruh kegiatan pengamatan terhadap suatu obyek atau orang lain. Proses ini dilakukan untuk mencari informasi dari observasi dan kemudian dilakukan penarikan kesimpulan mengenai sebab dan akibat. Ketika tahap penelitian ini dilakukan, peneliti melakukan observasi langsung ke tempat penelitian di Program Studi pada Perguruan Tinggi $X$.

\subsection{Metode Pembangunan Perangkat Lunak}

Metode yang dilakukan sewaktu untuk membangun sistem pada penelitian ini mengadopsi tahapan yang ada pada waterfall model [1]. Tahapan tersebut yaitu : 
a. Pendefinisian Kebutuhan (Requirements Definition)

Pada tahap ini dilakukan pengumpulan kebutuhan secara sistematis dan lengkap untuk kemudian dianalisis dan didefinisikan kebutuhan apa saja yang harus dipenuhi dan disediakan oleh sistem yang nantinya akan dibangun. Kebutuhan yang didefinisikan pada tahapan ini terdiri dari spesifikasi kebutuhan fungsional maupun non fungsional dari sistem yang akan dibangun.

b. Desain Sistem dan Perangkat Lunak (System and Software Design)

Pada tahap ini desain dikerjakan setelah kebutuhan selesai didefinisikan secara lengkap. Desain sistem merupakan perancangan sistem yang dilakukan berdasarkan data-data yang telah dikumpulkan pada tahap sebelumnya. Dalam tahap ini juga dilakukan desain secara internal maupun external dari sistem, mulai dari desain database, tampilan antarmuka sistem, pengkodean, sampai dengan desain dari input dan output sistem.

c. Implementasi Sistem (Implementation and Unit Testing)

Sewaktu tahapan implementasi dan pengujian sistem, dalam penelitian ini dilakukan dengan cara mengimplementasikan dari hasil spesifikasi kebutuhan dan hasil dari desain sistem yant telah dibuat sebelumnya, kedalam bahasa yang dapat dimengerti oleh komputer dengan menggunakan tools pemrograman. Selanjutnya dilakukan beberapa pengujian fungsional untuk mengetahui apakah sistem yang dibangun tersebut masih ada kesalahan atau sudah dapat berfungsi dengan baik.

d. Pengujian integrasi dan sistem (Integration and sistem testing)

Setelah sistem selesai diimplementasikan kedalam bahasa pemrograman, selanjutnya dilakukan beberapa pengujian fungsional untuk mengetahui apakah sistem yang dibangun tersebut masih ada kesalahan atau sudah dapat berfungsi dengan baik sesuai dengan kebutuhan.

e. Operasi dan Pemeliharaan (Operation and Maintenance)

Tahapan ini merupakan tahapan terakhir dalam penelitian yang dilakukan. Dalam tahap ini dilakukan pengoperasian sistem yang telah dibangun serta melakukan pemeliharaan dan perbaikan apabila sewaktu dioperasikan terdapat beberapa kesalahan.

Berikut ini adalah gambar dari metode yang digunakan untuk membangun sistem informasi pengumuman dapat dilihat pada Gambar 1 .

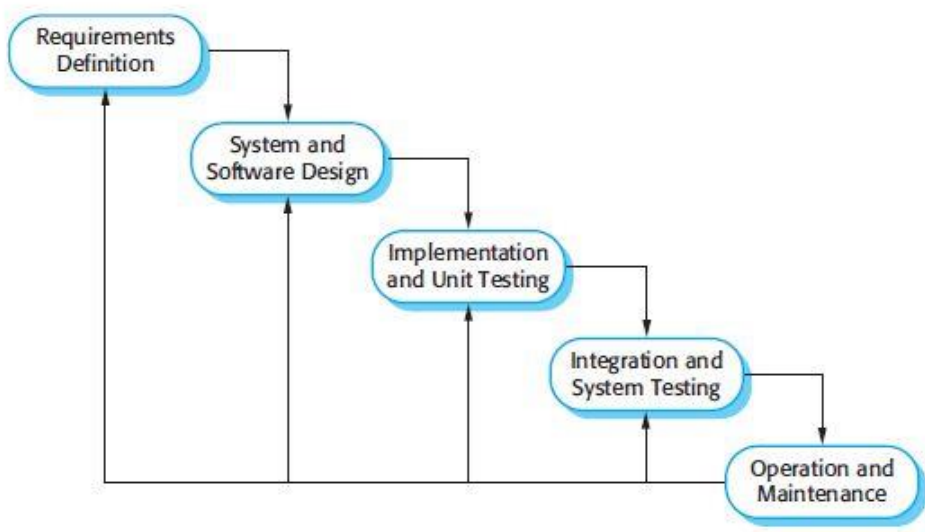

Gambar 1. Model Waterfall

\section{Kajian Pustaka}

\subsection{Konsep Dasar Sistem Informasi}

Sistem dapat diartikan sebagai suatu jaringan kerja dari berbagai macam prosedur yang saling berhubungan satu sama lain, prosedur tersebut dapat berbeda-beda tetapi bersama-sama 
untuk melakukan suatu kegiatan untuk menyelesaikan suatu sasaran atau tujuan tertentu [2]. Ada dua kelompok pendekatan dalam mendefinisikan sistem. Ada yang menekankan pada prosedurnya dan ada yang menekankan pada komponen atau elemennya [3].

Sedangkan Informasi merupakan hasil pengolahan dari sebuah model, rancangan, formasi, organisasi ataupun suatu perubahan bentuk dari data yang memiliki nilai tertentu serta bisa digunakan untuk menambah pengetahuan bagi yang menerimanya [2]. Kualitas informasi yang baik sangat dipengaruhi atau ditentukan dengan beberapa indikator. Indikator yang dapat digunakan untuk mengetahui kualitas informasi adalah relevance [4], accurate [5], completeness [4] [5], timeliness [6], dan understandability [6] [7] dari informasi yang dihasilkan.

Berdasarkan pengertian dari sistem dan informasi, maka Sistem Informasi dapat diartikan sebagai sekumpulan dari berbagai prosedur atau aturan yang dalam hal komputer bisa terdiri dari hardware, software dan brainware yang diorganisasikan secara menyeluruh untuk melakukan pengolahan data menjadi sebuah informasi yang berguna untuk memecahkan masalah maupun dalam hal pengambilan keputusan dari masalah yang sedang dihadapi [2].

\subsection{Sistem Pengolahan Data}

Data dapat diartikan sebagai segala sesuatu yang belum mempunyai arti apapun bagi penerimanya. Data diolah menggunakan komputer sebagai pengolah data agar bisa dimengerti oleh penerimanya. Dengan demikian dapat disimpulkan bahwa sistem pengolahan data merupakan sekelompok elemen atau fakta yang diolah untuk menghasilkan informasi yang dibutuhkan dalam proses pengambilan keputusan. Agar dapat menunjang suatu pengolahan data menjadi sebuah informasi perlu adanya teknologi yang dapat mengerjakan pengolahan data tersebut. Teknologi yang digunakan seperti komputer yang saling terkoneksi satu sama lain melalui jaringan baik itu intranet maupun internet.

\subsection{Definisi Basis Data}

Basis data merupakan suatu kumpulan data yang terhubung dan disimpan secara bersamasama pada suatu media penyimpanan. Data disimpan dengan cara-cara tertentu sehingga dapat dengan mudah untuk digunakan atau ditampilkan kembali, dapat digunakan oleh satu atau lebih sistem secara optimal. Data juga disimpan tanpa mengalami ketergantungan dengan program atau aplikasi yang akan menggunakannya, data juga disimpan agar pada saat proses penambahan, pengambilan dan modifikasi data dapat dilakukan dengan mudah dan lebih terkontrol dengan baik [8].

\subsection{Definisi Komunikasi}

Komunikasi berasal dari bahasa latin communication yang berarti pemberitahuan atau pertukaran pikiran. Dengan demikian dapat diartikan juga bahwa komunikasi adalah suatu rangkaian proses pengalihan informasi dari seseorang kepada orang lain dengan maksud tertentu dan tujuan tertentu. Agar dapat berkomunikasi dengan baik, maka beberapa hal yang harus diperhatikan yaitu informasi yang akan disampaikan, pengirim informasi (komunikator), media transmisi yang digunakan untuk mengirimkan informasi, penerima informasi dan tujuan dari informasi. Hal tersebut diperlukan baik itu ketika membangun sebuah komunikasi antar manusia maupun komunikasi antar komputer.

\subsection{Proses Komunikasi}

Proses komunikasi adalah setiap langkah mulai dari saat menciptakan informasi sampai dipahami oleh penerima informasi. Beberapa langkah yang dilakukan ketika proses komunikasi adalah sebagai berikut]:

a. Tahapan awal yakni gagasan atau ide diciptakan oleh sumber atau pengirim informasi.

b. Setelah ide atau gagasan diciptakan, tahapan selanjutnya yaitu dirubah menjadi pesan informasi yang sesuai aturan komunikasi sehingga mempunyai makna dan dapat dikirimkan. Tahapan ini biasa dikenal dengan istilah proses encoding informasi.

c. Setelah pesan informasi selesai di-encoding, langkah selanjutnya yaitu mengirimkan pesan informasi tersebut melalui media transmisi yang digunakan. 
d. Setelah pesan informasi dikirimkan melalui media transmisi yang digunakan, maka pesan tersebut dapat diterima oleh penerima informasi setelah melaui proses decoding agar dapat dimengerti oleh penerima informasi.

e. Komunikasi dapat dikatakan lengkap apabila penerima pesan informasi telah memberi informasi kepada pengirim pesan bahwa informasi telah diterima dan dimengerti dengan baik oleh penerima pesan informasi.

\subsection{Pengumuman}

Pengumuman merupakan informasi yang disampaikan kepada seseorang ataupun kelompok yang menjadi tujuan. Pemberian pengumuman bertujuan yaitu untuk menyampaikan sesuatu yang dapat berupa informasi atau pesan agar supaya dapat diketahui oleh seseorang ataupun kelompok [9]. Pengumuman dapat dibuat dalam menanggapi sesuatu seperti informasi, rumor atau dapat dibuat untuk alasan positif seperti pengenalan produk [9].

Jenis pengumuman terbagi menjadi dua, yang pertamayaitu jenis pengumuman berdasarkan sifatnya yang didalamnya terdiri dari pengumuman format atau resmi serta pengumuman tidak resmi, serta yang kedua jenis pengumuman berdasarkan pihak yang mengeluarkan yang terdiri dari pengumuman dari perseorangan dan pengumuman dari lembaga.

\subsection{Media Informasi Pengumuman}

Salah satu media informasi yang sering digunakan untuk memberikan informasi yaitu menggunakan dengan media papan pengumuman. Papan pengumuman dapat ditemui di setiap instansi atau organisasi. Hal tersebut dikarenakan papan pengumuman merupakan salah satu media komunikasi yang ditujukan untuk target sasaran dalam lingkup kelompok tertentu.

Media papan pengumuman merupakan salah satu media yang paling efektif. Pada lingkup sebuah organisasi, media papan pengumuman biasanya ditempatkan di tempat yang dapat dibaca dengan jelas. Informasi yang dipasang di papan pengumuman meliputi pemberitahuan serta informasi. Berikut ini merupakan contoh papan informasi pengumuman yang dapat dilihat pada Gambar 2:

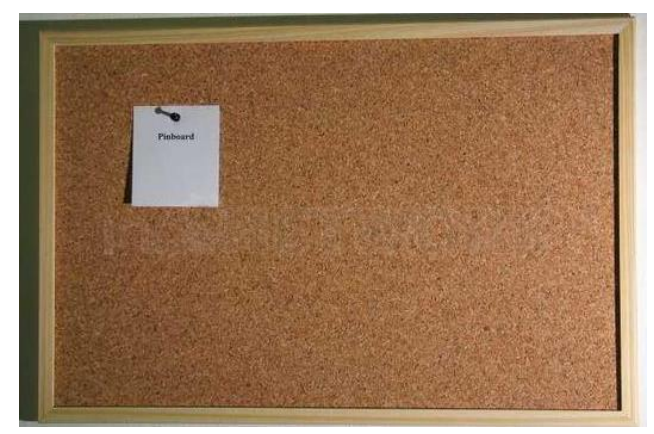

Gambar 2. Contoh Papan Informasi Pengumuman

\section{Hasil dan Pembahasan}

\subsection{Proses pembuatan dan penyampaian informasi Program Studi di Perguruan Tinggi $X$}

Berikut merupakan proses pembuatan dan penyampaian informasi di Program Studi pada Perguruan Tinggi $X$ :

a. Dosen membuat informasi pengumuman yang akan disampaikan kepada mahasiswa salah satu program studi menggunakan aplikasi pengolah kata.

b. Dosen menyimpan informasi pengumuman ke dalam media penyimpanan eksternal.

c. Dosen mencetak informasi pengumuman di Sekretariat Program Studi pada Perguruan Tinggi $X$

d. Dosen menempelkan informasi pengumuman di papan pengumuman Program Studi di Perguruan Tinggi $X$ 
e. Mahasiswa melihat informasi pengumuman di papan pengumuman Program Studi pada Perguruan Tinggi $X$

Berikut ini adalah gambar proses pembuatan dan penyampaian informasi di salah satu Program Studi pada Perguruan Tinggi $X$ :

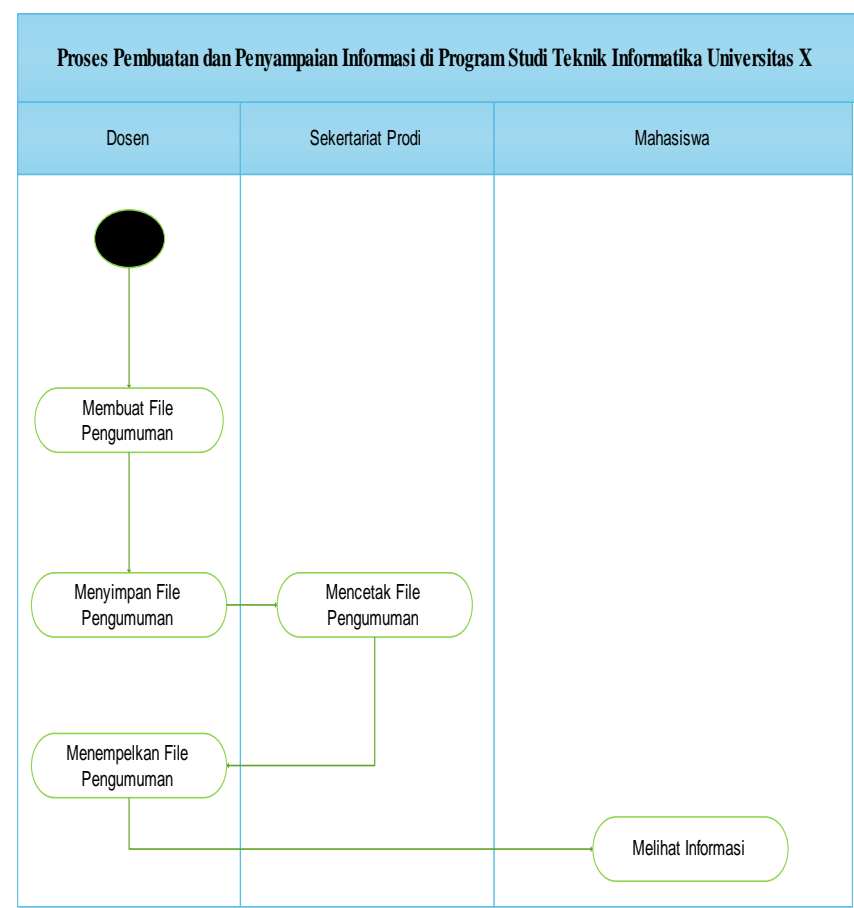

Gambar 3. Proses Pembuatan dan Penyampaian Informasi di Program Studi Perguruan Tinggi $X$

\subsection{Analisis Kebutuhan Perangkat Keras}

Adapun kebutuhan perangkat keras yang dibutuhkan untuk mengimplementasikan sistem ini selengkapnya dapat dilihat secara garis besar pada Tabel 1 berikut:

Tabel 1. Kebutuhan Perangkat Keras

\begin{tabular}{|c|c|c|}
\hline Gambar Perangkat Keras & Jenis Perangkat Keras & Spesifikasi \\
\hline $\bar{\sigma}$ & $\begin{array}{l}\text { Komputer Desktop Untuk } \\
\text { Pengolah Informasi }\end{array}$ & $\begin{array}{l}\text { Motherboard Asrock } \\
\text { Intel Dual Core Prosesor } \\
\text { Harddisk WD } \\
\text { Samsung DVD ROM } \\
\text { Case PowerLogic Gusto + } \\
\text { PowerSupply }\end{array}$ \\
\hline$=$ & $\begin{array}{l}\text { Televisi atau Monitor } \\
\text { Untuk Informasi }\end{array}$ & $\begin{array}{l}\text { : Toshiba LED } \\
\text { : } 32-42 \text { “ } \\
\text { : Hitam } \\
\text { : H163HQ }\end{array}$ \\
\hline
\end{tabular}




\begin{tabular}{|c|c|c|}
\hline Gambar Perangkat Keras & Jenis Perangkat Keras & Spesifikasi \\
\hline & $\begin{array}{l}\text { TP LINK Wireless Router } \\
\text { Untuk Media Transmisi } \\
\text { Komunikasi }\end{array}$ & Router Wireless-N \\
\hline & $\begin{array}{l}\text { Bracket } \\
\text { Untuk Tempat Televisi atau } \\
\text { Monitor ditempelkan di } \\
\text { dinding }\end{array}$ & $\begin{array}{l}\text { Bracket TV untuk tv led/lcd/plasma } \\
24 "-50\end{array}$ \\
\hline
\end{tabular}

\subsection{Analisis Kebutuhan Perangkat Lunak}

Adapun kebutuhan perangkat lunak yang diperlukan dalam pembangunan sistem informasi pengumuman dibedakan kedalam perangkat lunak untuk pembangunan dan perangkat lunak untuk implementasi.

Kebutuhan perangkat lunak untuk pembangunan dan implementasi sistem yaitu:

a. Sistem Operasi menggunakan Microsoft Windows 7/8.1/10

b. Macromedia Dreamweaver 8

c. XAMPP Versi 1.7

d. Aplikasi Microsoft Office

e. Browser Mozilla Firefox

\subsection{Arsitektur Jaringan Sistem Informasi Pengumuman Program Studi di Perguruan Tinggi $X$}

Berikut merupakan Gambar 4 mengenai rancangan arsitektur sistem informasi pengumuman Program Studi di Perguruan Tinggi $X$.

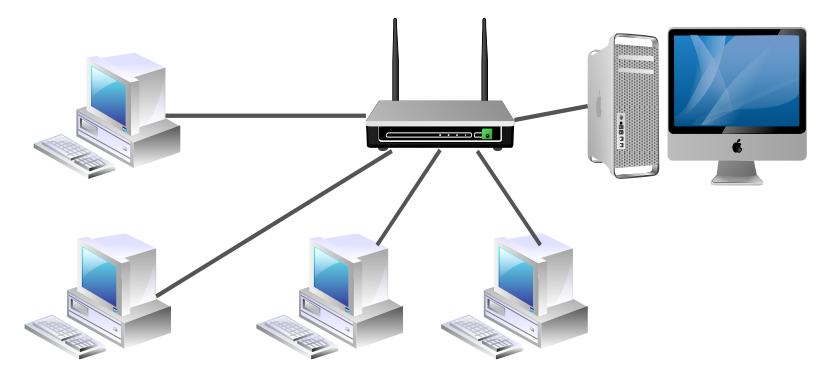

Gambar 4. Arsitektur Jaringan Sistem Informasi Pengumuman

\subsection{Perancangan Cara Kerja Sistem Secara Keseluruhan}

Sistem informasi pengumuman yang rencananya akan diimplementasikan di setiap program studi di Perguruan Tinggi X, mempunyai cara kerja seperti berikut:

a. Sistem ini berbasis client server, dimana yang menjadi client adalah komputer dosen atau sekretariat di program studi, sedangkan yang menjadi server yaitu komputer khusus yang menyimpan data pengumuman yang akan di tampilkan kepada mahasiswa.

b. Sistem ini akan aktif berdasarkan masukan tanggal aktif dan tanggal tidak aktif yang di inputkan oleh dosen atau sekretariat program studi sebagai pembuat pengumuman.

c. Sistem ini akan menampikan informasi seperti slide power point yang akan berganti informasi selama 30 detik sekali.

d. Sistem ini akan mengkonversi dari file power point yang di unggah oleh dosen atau sekretariat di Program Studi pada Perguruan Tinggi X menjadi file gambar. 
4.6. Perancangan Tampilan Antar Muka Sistem Informasi Pengumuman Program Studi di Perguruan Tinggi $X$

Gambar 5 sampai dengan Gambar 8 berikut ini merupakan beberapa rancangan tampilan antar muka Sistem Pengumuman Program Studi di Perguruan Tinggi $X$

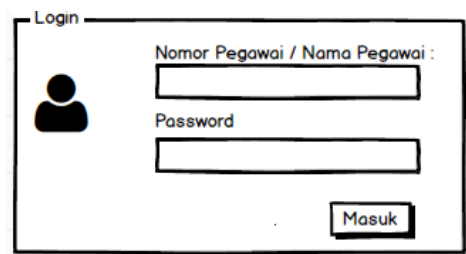

Gambar 5. Rancangan Antarmuka Tampilan Login Sistem Informasi Pengumuman

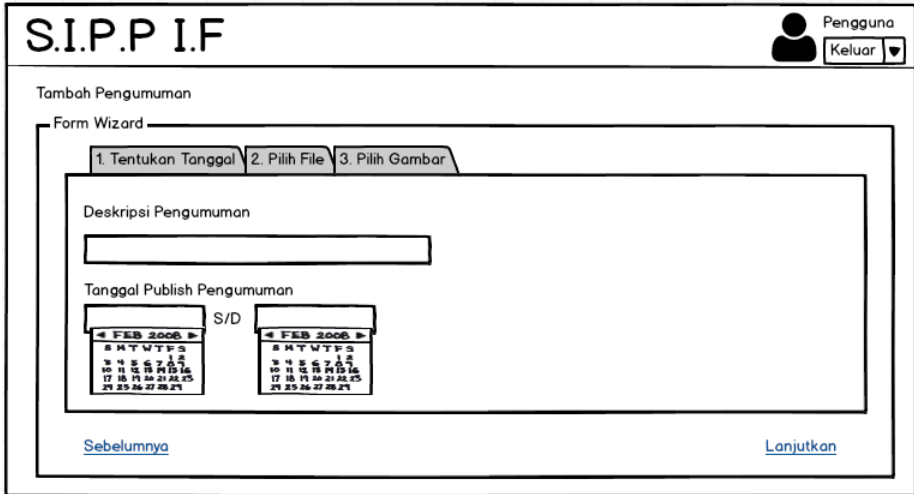

Gambar 6. Rancangan Antarmuka Tampilan Mengisi Deskripsi Pengumuman dan Menentukan Tanggal Mulai dan Tanggal Akhir Pengumuman

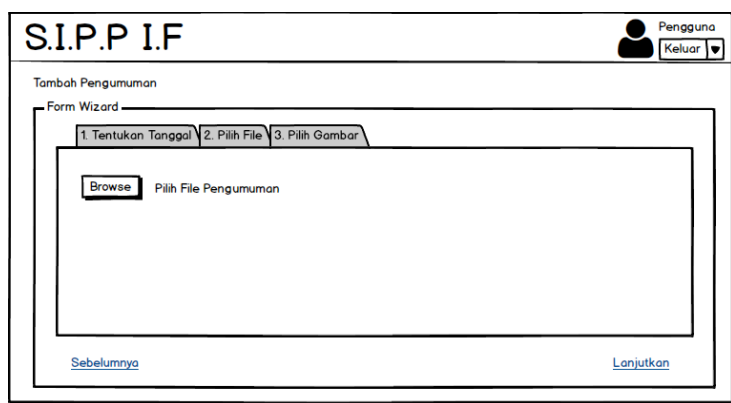

Gambar 7. Rancangan Antarmuka Tampilan Sistem Memilih File Power Point

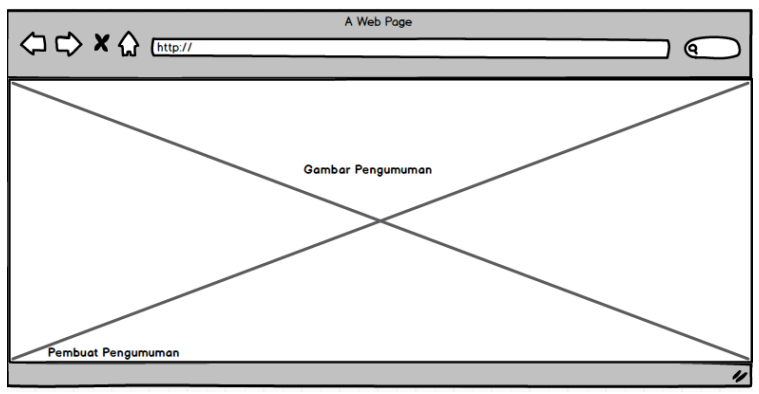

Gambar 8. Rancangan Antarmuka Tampilan Sistem pengumuman yang akan di tampilkan di Layar Televisi 


\subsection{Skema Relasi Database Sistem Informasi Pengumuman Program Studi di Perguruan} Tinggi $X$

Skema relasi digunakan untuk menggambarkan hubungan diantara dua tabel atau lebih pada sebuah database sistem. Berikut ini adalah skema relasi sistem informasi pengumuman program studi di Perguruan Tinggi $X$ yang dapat dilihat pada Gambar 9.

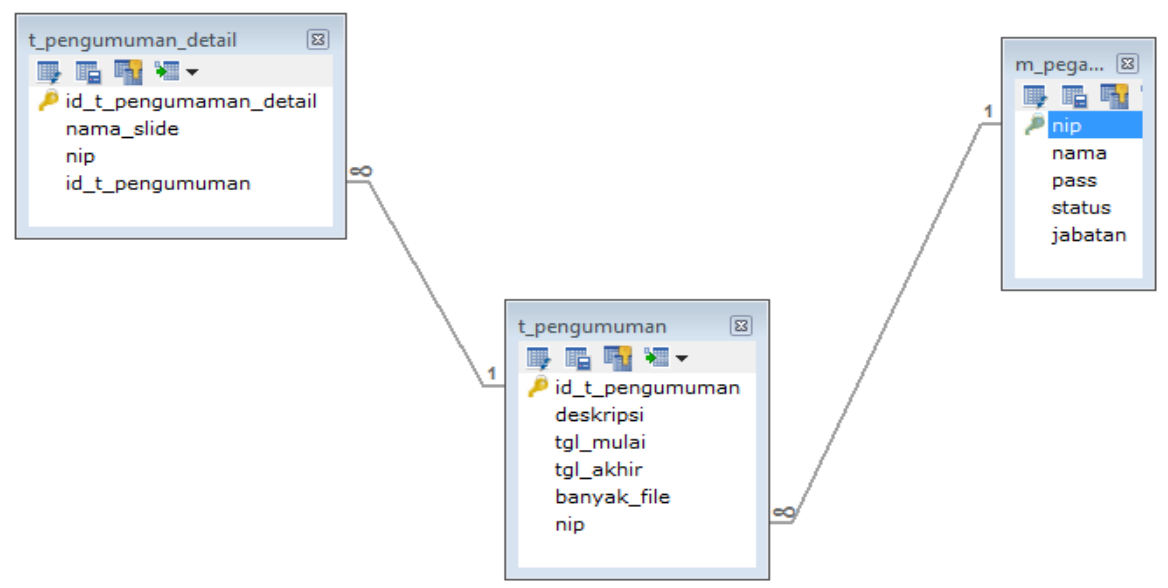

Gambar 9. Skema Relasi Sistem Informasi Pengumuman

\subsection{Implementasi Sistem Informasi Pengumuman Program Studi di Perguruan Tinggi $X$}

Tahap implementasi sistem merupakan tahap menjalankan sistem yang telah dirancang sebelumnya. Gambar 10 sampai dengan Gambar 13 merupakan tampilan dari hasil implementasi sistem yang telah dibangun.

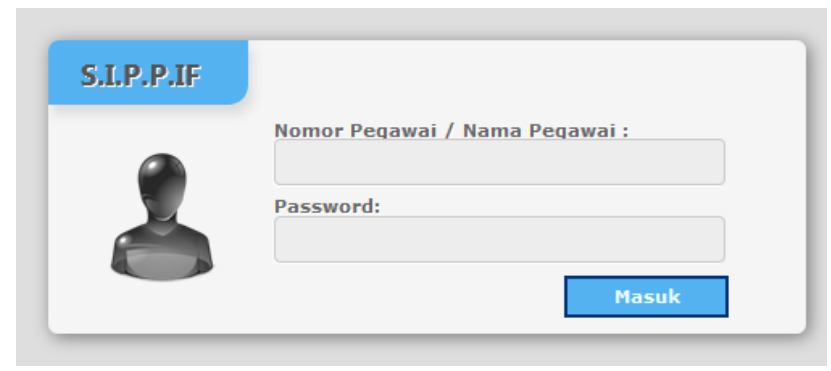

Gambar 10. Implementasi Tampilan Login Sistem Informasi Pengumuman 


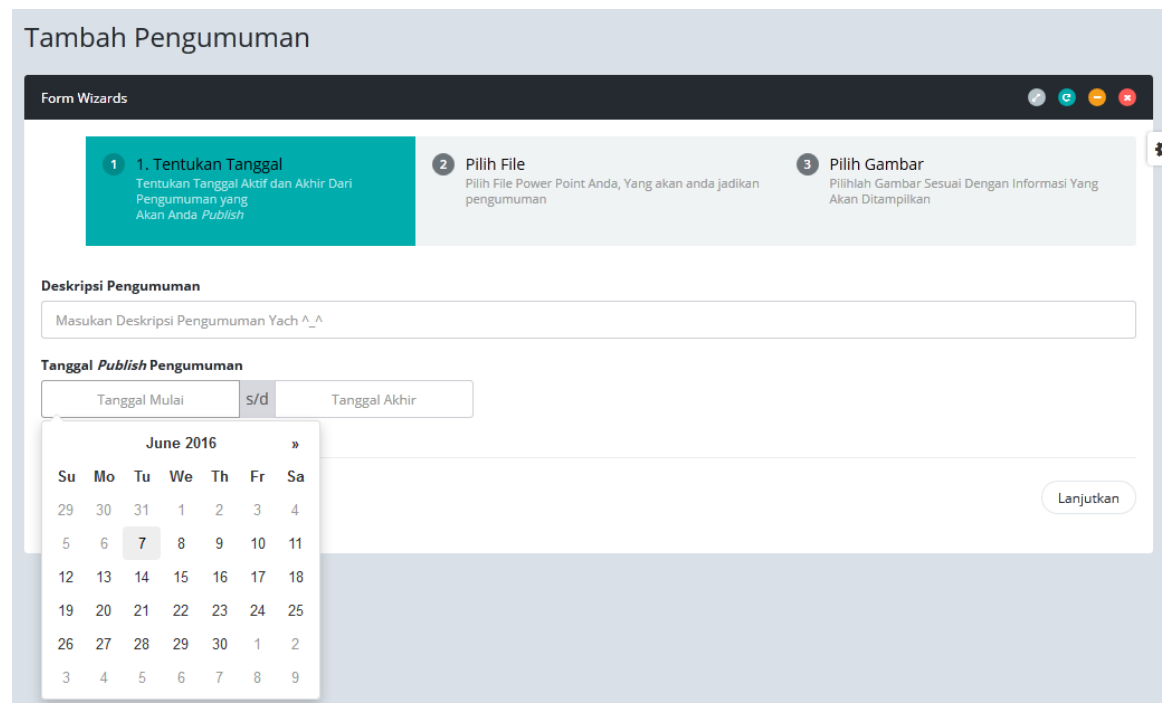

Gambar 11. Implementasi Tampilan Mengisi Deskripsi Pengumuman dan Menentukan Tanggal Mulai dan Tanggal Akhir Pengumuman

Tambah Pengumuman

\section{Form Wizards}

(1) Tentukan Tanggal

Tentukan Tanggal Aktif dan Akhir Dar

Pengumuman yang

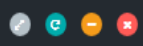

Browse.. 1. Pertemuan Ke 1 - Aturan Perkuliahan \& Materi.pptx

\section{Pilih File}

Pilih File Power Point Anda, Yang akan anda jadikan

pengumuman
(3) Pilih Gambar

Pilihlah Gambar Sesuai Dengan Informasi Yang Akan Ditampilkan

Gambar 12. Implementasi Tampilan Sistem Memilih File Power Point

\section{Pilih File Gambar}

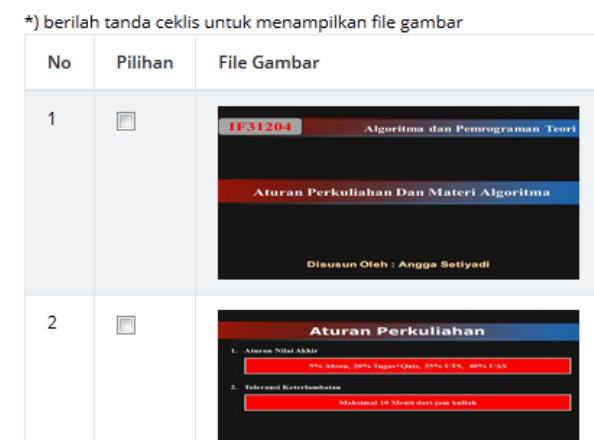

Gambar 13. Tampilan Sistem Memilih File Gambar 
Setelah sistem informasi pengumuman selesai diimplementasikan, peneliti melakukan uji coba atau testing langsung terhadap sistem dan para stakeholder atau pengguna sistem. Berdasarkan hasil pengujian wawancara dan pengujian blackbox yang dilakukan, didapatkan kesimpulan bahwa dari semua fungsional sistem secara umum pada beberapa proses fungsional masih ditemukan kesalahan minor, tetapi secara umum sistem yang dibangun sudah dapat menghasilkan output atau tujuan yang sesuai dengan harapan.

\section{Kesimpulan}

Adapun kesimpulan yang bisa didapatkan bahwa penelitian ini sudah menghasilkan sistem informasi pengumuman Program Studi di Perguruan Tinggi $X$ sehingga dapat membantu pihak Dosen dan Sekretariat Program Studi dalam memberikan informasi kepada mahasiswa. Dengan adanya sistem ini proses penyampaian informasi dapat berubah menjadi media digital sehingga dapat meningkatkan efektifitas dan efisiensi pada proses penyampaikan informasi.

\section{Daftar Pustaka}

[1] R. S. Pressman, Software Engineering, New York: McGrawHill, 2010.

[2] Jogiyanto, Analisis dan Desain, Yogyakarta: Andi Publisher, 2009.

[3] F. Andalia and E. B. Setiawan, "Pengembangan Sistem informasi Pengolahan Data Pencari Kerja Pada Dinas Sosial dan Tenaga Kerja Kota Padang," Jurnal Ilmu Komputer dan Informasi, vol. 4, no. 2, pp. 93-98, 2015.

[4] R. Mcleod, "Management Information Systems Chapter 8," in Management Information Systems, 2008.

[5] J. livari, "An empirical test of the DeLone-McLean model of information system success," ACM SIGMIS Database, 2005.

[6] E. R. Delone, W.H. and McLean, "The DeLone and McLean Model of Information Systems Success: A Ten-Year Update," Journal of Management Information Systems, 2003.

[7] G. G. Gable, D. Sedera, and T. Chan, "Enterprise Systems Success: A Measurement Model," International Conference of Information Systems, 2003.

[8] Fatansyah, Basis Data, Bandung: Informatika, 2002.

[9] Business Dictionary, "Deffiniton Announcement." [Online]. Available: http://www.businessdictionary.com/definition/announcement.html. [Accessed: 09-Nov2016]. 